Jurnal Agro 8(1), 2021

\title{
PENGARUH FAKTOR LINGKUNGAN TERHADAP PERTUMBUHAN BEBERAPA AKSESI Dioscorea alata L. TERPILIH KOLEKSI KEBUN RAYA PURWODADI
}

\section{ENVIRONMENTAL FACTORS ON THE GROWTH OF Dioscorea alata L. SELECTED ACCESSIONS OF PURWODADI BOTANICAL GARDEN COLLECTION}

\author{
Abban Putri Fiqa ${ }^{1}$, Titik Helen Nursafitri' ${ }^{2}$ Fauziah $^{1}$, Shofiyatul Masudah ${ }^{1}$ \\ ${ }^{1}$ Balai Konservasi Tumbuhan Kebun Raya Purwodadi-Pusat Penelitian Konservasi Tumbuhan \\ dan Kebun Raya-LIPI \\ Jalan Raya Surabaya - Malang No.Km. 65, Sembung Lor, Parerejo, Kec. Purwodadi, Pasuruan, \\ Jawa Timur 67163 \\ ${ }^{2}$ Fakultas Sains dan Teknologi, Universitas Islam Negeri Maulana Malik Ibrahim, Malang \\ JI. Gajayana No.50, Dinoyo, Kec. Lowokwaru, Kota Malang, Jawa Timur 65144
}

Korespondensi: abbanpf@gmail.com

Diterima : 16 Desember 2020 /Disetujui : 24 Mei 2021

\begin{abstract}
ABSTRAK
Uwi (Dioscorea alata L.) merupakan jenis tanaman umbi-umbian berpotensi nutrisi. Namun pemanfaatannya sebagai bahan pangan alternatif masih jarang, karena keterbatasan informasi potensi nutrisi dan sistem budidaya. Penelitian ini bertujuan untuk menentukan faktor-faktor lingkungan yang berpengaruh terhadap pertumbuhan uwi. Penelitian dilakukan di lahan percobaan di Kabupaten Pasuruan, pada tujuh aksesi yang dipilih berdasarkan hasil penelitian sebelumnya, yaitu aksesi nomor 28, 36, dan 86 (Pasuruan), 42 dan 43 (Nganjuk), 57 dan 66 (Malang). Parameter lingkungan yang diamati meliputi suhu udara, kelembaban udara, intensitas cahaya, $\mathrm{pH}$ tanah, kelembaban tanah, jumlah dan jenis gulma. Hasil pengamatan dianalisis secara deskriptif dan statistik dengan uji Biplot menggunakan software Past 3. Hasil penelitian menunjukkan bahwa intensitas cahaya dan jumlah jenis gulma merupakan faktor lingkungan yang paling berpengaruh pada pertumbuhan tanaman uwi. Terdapat tiga grup aksesi tanaman uwi berdasarkan perbedaan faktor lingkungan yang mempengaruhi pertumbuhannya. Aksesi 42, 43 dan 57 dipengaruhi oleh suhu dan kelembaban udara, aksesi 28, 36 dan 66 dipengaruhi oleh intensitas cahaya dan aksesi 86 dipengaruhi oleh pH tanah. Analisis deskriptif menunjukkan bahwa sebagian besar gulma yang tumbuh merupakan tanaman invasif yang mempengaruhi pertumbuhan tanaman komoditas. Aksesi nomor 42, 43 dan 57 direkomendasikan untuk dibudidayakan di lahan sub optimal dengan kondisi $\mathrm{pH}$ asam dan minim air.
\end{abstract}

Kata Kunci : aksesi terpilih, Dioscorea alata L., faktor biotik, faktor abiotik, pertumbuhan.

\begin{abstract}
Water yam (Dioscorea alata L.) is one of the tubers potentially as nutrition source. However, its utilization as the source of food alternative is still rare causes by limited information about

ISSN : 2407-7933

Cite this as: Fiqa, A. P., Nursafitri, T. H., Fauziah. \& Masudah S. (2021). Pengaruh faktor lingkungan terhadap pertumbuhan beberapa aksesi Dioscorea alata $\mathrm{L}$ terpilih koleksi kebun raya purwodadi. Jurnal Agro, 8(1), 25-39. https://doi.org/10.15575/10594
\end{abstract}


its nutritional content and cultivation. The research aimed to determine the environmental factors effects the growth of water yam. The study was conducted in the trial site at Pasuruan with seven selected accessions of water yam based on previous research i.e. accessions number 28, 36 and 86 (Pasuruan), 42 and 43 (Nganjuk), 57 and 66 (Malang). The observed environmental parameters were the number and type of weeds, temperature, humidity, light intensity, soil pH, and soil moisture. The observations were descriptive and statistically analyzed using Biplot test with Past 3 software. The results showed that the light intensity and the number of weed species are the environmental factors that have the most affected on the growth of water yam plants. Accessions 28, 36 and 66 are affected by light intensity, accession 86 is affected by soil pH, and accessions 42,43 and 57 are affected by air temperature and humidity. Most of the weeds grown in the study area are invasive species, which affect the growth of cultivated crops, so weeding is needed. Accession number 42, 43 and 57 adaptively grow in sub-optimum land with acidic $\mathrm{pH}$ conditions and minimum water capacity.

Keywords: selected accessions, Dioscorea alata L., growth, biotic factors, abiotic factors.

\section{PENDAHULUAN}

Upaya pengembangan bahan pangan subtitusi sebagai sumber karbohidrat alternatif sangat diperlukan saat ini. Ketersediaan bahan pokok saat ini masih sangat bergantung pada beras, sedangkan produksi padi pada suatu saat dapat terjadi penurunan sehingga tidak memenuhi kebutuhan masyarakat (Hasan, 2010; Kinasih et al., 2017). Oleh karena itu diversifikasi pangan perlu dilakukan, salah satunya pada uwi (Dioscorea alata).

Uwi merupakan salah satu jenis umbiumbian yang berpotensi untuk dikembangkan dalam memenuhi kebutuhan pangan lokal. Uwi berpotensi sebagai sumber karbohidrat yang bernutrisi tinggi (Herison \& Turmudi, 2010; Kinasih et al., 2017) dengan komposisi kimia uwi diketahui terdiri atas $77,75 \%$ air, $16,82 \%$ pati, 2,05\% protein, 0,01\% lemak dan $0.83 \%$ abu (Harzau \& Estiasih, 2013). Selain itu diketahui pula bahwa uwi sangat bermanfaat untuk kesehatan. Uwi seperti diketahui, memiliki kandungan lendir kental terdiri dari gliko protein dan polisakarida yang larut dalam air. Polisakarida larut air (PLA) adalah serat pangan yang bersifat hidrokoloid dan bermanfaat untuk menurunkan kadar glukosa dalam darah dan kadar total kolesterol dalam tubuh (Munawaroh et al., 2018), selain itu beberapa aksesi lokal tanaman uwi ini merupakan sumber karbohidrat yang baik untuk diet karena mengandung serat yang tinggi dan kandungan lemak yang rendah (Fauziah et al., 2020). Kandungan nutrisi yang tinggi pada uwi menyebabkan uwi perlu dikembangkan lebih lanjut.

Akan tetapi bahan pangan berbahan dasar uwi yang dulu banyak dikonsumsi masyarakat, kini mulai ditinggalkan, karena bentuk penyajiannya yang cenderung monoton dan tidak bervariasi, juga karena rasanya yang tidak dapat berubah. Namun penelitian yang dilakukan belakangan ini mencatat bahwa uwi dapat diolah lebih lanjut menjadi berbagai macam bahan makanan yang lebih menarik seperti keripik, nugget, stik, french fries dan hashbrown (Munawaroh et al., 2018; Pradini et al., 2019). Hasil olahan tepung uwi juga telah berhasil dimanfaatkan untuk pembuatan berbagai bahan pangan seperti donat, stik uwi, dan berbagai bahan pangan lainnya 
(Hapsari, 2014). Sehingga variasi olahan diperlukan untuk dapat meningkatkan nilai potensi pangan dan kebermanfaatannya.

Hasil penelitian yang dilakukan sebelumnya melaporkan bahwa uwi memiliki banyak varietas lokal dengan kondisi dan keunggulan yang berbeda-beda. Jawa Timur sendiri menurut laporan penelitian sebelumnya, tercatat memiliki banyak varian uwi yaitu sekitar 35 varian (Hapsari, 2014; Fauziah et al., 2017). Kebun Raya Purwodadi memiliki beberapa koleksi varietas lokal yang didapatkan dari eksplorasi lokal di sekitar Jawa Timur, meliputi area Nganjuk, Pasuruan, dan Malang. Dari eksplorasi yang dilakukan di daerah-daerah tersebut, didapatkan 15 aksesi terpilih, yang unggul dalam morfologi, produktivitas serta kandungan nutrisinya.

Kelima belas aksesi terpilih tersebut antara lain adalah aksesi nomor 28, 29, 30, $31,32,36,57,63,64,66,67,82$, dan 86 . Aksesi terpilih tersebut berasal dari tiga area lokasi yang berbeda, dan setelah diuji nutrisi memiliki keunggulan yang berbeda-beda pula (Fauziah et al., 2017; Fauziah et al., 2020). Akan tetapi, pengetahuan masyarakat mengenai keunggulan-keunggulan nilai nutrisi yang dimiliki uwi dan cara budidayanya yang efektif masih sangat kurang (Fauziah \& Mas'udah, 2015). Sehingga, edukasi pada masyarakat mengenai potensi uwi dan cara budidayanya masih diperlukan.

Lingkungan tempat tumbuh yang optimum dapat menyebabkan pertumbuhan dan perkembangan tanaman menjadi optimum. Pertumbuhan tanaman sangat dipengaruhi oleh faktor genetik dan lingkungan tempat tumbuhnya (Herison \& Turmudi, 2010). Menurut Abdillah (2015), uwi sebagian besar ditanam pada lahanlahan yang cenderung kering, dengan kondisi minim air, serta cukup adaptif tumbuh mulai dari dataran rendah hingga dataran tinggi dengan ketinggian $2000 \mathrm{~m}$ dpl. Secara agronomi, uwi memiliki keunggulan mudah diperbanyak, daya hasil tinggi serta toleran pada lahan yang miskin hara dan minim air (Padhan \& Panda, 2020; Takada et al., 2017). Lebih jauh lagi diketahui nilai nutrisi yang berbeda pada varian uwi dipengaruhi oleh iklim lingkungan, tingkat kematangan umbi, masa panen dan karakteristik tanah di mana uwi tersebut dibudidayakan (Baah, 2009; Bhandari et al., 2003). Sehingga informasi mengenai faktor lingkungan yang mempengaruhi budidaya sangat diperlukan.

Selain faktor lingkungan abiotik, faktor lingkungan biotik seperti gulma, juga perlu untuk diketahui. Keberadaan salah satu jenis gulma yang berupa invasive species (Mikania micrantha), diketahui menjadi penyebab menurunnya produksi kelapa sawit di area perkebunan di Jambi (Adriadi et al., 2012). Inventarisasi gulma sebelum tindakan pengendalian diperlukan untuk menerapkan pengendalian gulma yang efektif dan efisien pada suatu area pertanian. Bagaimanapun pengendalian gulma merupakan bagian dari pengelolaan organisme pengganggu yang merupakan komponen pokok dalam proses produksi pertanian.

Selama ini di Indonesia, penelitian mengenai kesesuaian lahan untuk pertumbuhan Dioscorea alata sangat jarang dilakukan, terutama pada varian-varian lokal yang memiliki keunggulan-keunggulan yang spesifik. Penelitian sebagian besar dilakukan untuk menguji perlakuan tanam (Martin et al., 2012; Mansur et al., 2015), maupun mengenai karakter morfologi (Purnomo et al., 2012; Trimanto, 2012; Anokye et al., 2014; Kinasih et al., 2017;), genetik dan kandungan kimianya pada berbagai varian dan lokasi tumbuhnya (Purnomo et al., 2016; 
Fauziah et al., 2020). Oleh sebab itu, penelitian ini penting dilakukan untuk mengisi gap pada tahap awal pertumbuhan uwi.

Penelitian ini diperlukan untuk memaksimalkan pertumbuhan dan produktivitas tiap aksesi yang memiliki kebutuhan yang berbeda-beda dan merupakan langkah penting dalam menyusun pedoman budidaya yang tepat untuk aksesi uwi di Jawa Timur. Penelitian dilakukan bertujuan untuk mengidentifikasi faktor lingkungan (abiotik maupun biotik) yang berpengaruh bagi pertumbuhan beberapa aksesi lokal uwi koleksi Kebun Raya Purwodadi yang ditanam di lahan percobaan.

\section{BAHAN DAN METODE}

Penelitian dilakukan pada tujuh aksesi varietas lokal uwi yaitu aksesi nomor 28, 36, dan 86 (berasal dari Kabupaten Pasuruan), aksesi 42 dan 43 (berasal dari Kabupaten Nganjuk), aksesi nomor 57 dan 66 (berasal dari Kabupaten Malang). Pemilihan aksesi didasarkan pada keunggulan nutrisi pada umbi yaitu: aksesi 28 (lemak rendah), aksesi 36 (serat tinggi, karbohidrat tinggi), aksesi 42 (lemak rendah, protein tinggi), aksesi 43 (karbohidrat tinggi), aksesi 57 (karbohidrat rendah), aksesi 66 (protein tinggi, lemak rendah) dan aksesi 86 (karbohidrat rendah, protein tinggi, rata-rata bobot umbi tinggi) (Fauziah \& Mas'udah, 2015; Fauziah et al., 2020) serta ketersediaan umbinya untuk dijadikan bibit. Penelitian dilakukan selama 3 bulan, yaitu Bulan Juni-Agustus 2019.

Lahan percobaan terletak di Dusun Parelegi, Desa Purwodadi, Kecamatan Purwodadi, Kabupaten Pasuruan, pada ordinat 7'81'3771" LS dan 112 $73^{\circ} 0759$ BT. Total luas lahan yang digunakan adalah 3500 $\mathrm{m}^{2}$ dan tiap aksesi ditanam sebanyak 10 tanaman ulangan. Lahan percobaan merupakan lahan bekas sawah yang sudah lama tidak dimanfaatkan kembali, dengan ketersediaan air yang rendah.

Pengamatan dilakukan pada vegetatif tanaman uwi yang berusia 6 bulan yaitu panjang ruas batang dan lingkar batang. Selain itu diamati pula generatif tanaman yaitu jumlah tanaman yang berbunga. Parameter lingkungan biotik diwakili dengan inventarisasi gulma pada area penelitian, menggunakan petak contoh berukuran $50 \mathrm{x}$ $50 \mathrm{~cm}^{2}$. Jenis dan kelimpahan tiap spesies dicatat dan dihitung. Hasil yang didapatkan dianalisis dengan mencari kerapatan, frekuensi, dan dominansi untuk selanjutnya didapatkan Indeks Nilai Penting masingmasing jenisnya.

Parameter lingkungan abiotik yang diamati meliputi suhu dan kelembaban udara (diamati dengan thermohygrometer) serta intensitas cahaya (dengan Luxmeter). Sifat fisik tanah yaitu $\mathrm{pH}$ dan kelembaban tanah diamati dengan soil tester. Pengamatan faktor lingkungan dilakukan seminggu sekali pada jam yang sama di masing-masing lokasi penanaman tiap aksesi.

Data yang didapatkan kemudian ditabulasi baik untuk faktor biotik maupun faktor abiotik. Data vegetatif dan generatif tanaman, jumlah jenis gulma dan kelimpahan gulma, serta data faktor abiotik ditabulasi dan dianalisis biplot dengan bantuan software PAST 3, untuk mengetahui faktor lingkungan yang mempengaruhi pertumbuhan dan produktivitas tanaman uwi pada tiap aksesi yang berbeda. Data jenis dan Indeks Nilai Penting masing-masing gulma yang diinventarisasi di lahan percobaan dianalisis secara deskriptif, sebagai tambahan, untuk mengidentifikasi 
jenis-jenis yang diinvasif, data gulma dicocokkan dengan database tanaman invasif pada www.cabi.org/isc/datasheet/.

\section{HASIL DAN PEMBAHASAN}

Secara umum, kondisi lingkungan di area penelitian digambarkan pada Tabel 1. Area Kecamatan Purwodadi, Kabupaten Pasuruan terletak pada ketinggian $300 \mathrm{~m}$ dpl, dengan iklim yang cenderung kering, ditandai dengan kelembaban udaranya yang rendah, berkisar antara 38,00-57,83\%. Lahan percobaan yang ditanami uwi ini terdapat beberapa area yang ternaungi pohon, namun ada pula area yang sangat terbuka, sehingga intensitas cahayanya juga sangat beragam, berkisar antara 3235-12456 Lux. Suhu udara tertinggi di area lahan percobaan juga termasuk tinggi, yaitu hingga mencapai $40,60^{\circ} \mathrm{C}$. Selain udaranya yang kering, kondisi tanah di lahan percobaan juga cenderung kering, berkisar antara 47,67$65,00 \%$.

Tabel 1. Rerata faktor lingkungan abiotik di lahan percobaan uwi di Kecamatan Purwodadi, Kabupaten Pasuruan

\begin{tabular}{lc}
\hline \multicolumn{1}{c}{ Faktor Lingkungan Abiotik } & Nilai \\
\hline Intensitas Cahaya (lux) & $3235-12456$ \\
Kelembaban Udara (\%) & $38,00-57,83$ \\
Suhu Udara $\left({ }^{\circ} \mathrm{C}\right)$ & $29,23-40,60$ \\
Kelembaban Tanah $(\%)$ & $47,67-65,33$ \\
pH tanah & $4,20-5,93$ \\
\hline
\end{tabular}

Kondisi tanah cenderung asam, dengan nilai $\mathrm{pH}$ di bawah 6. Curah hujan di Kecamatan Purwodadi berkisar antara 0 $15,13 \mathrm{ml}$ dalam setahun (Gambar1).
Berdasarkan analisis vegetasi yang dilakukan terhadap gulma yang tumbuh pada area percobaan, didapatkan hasil seperti yang ditunjukkan pada Tabel 2.

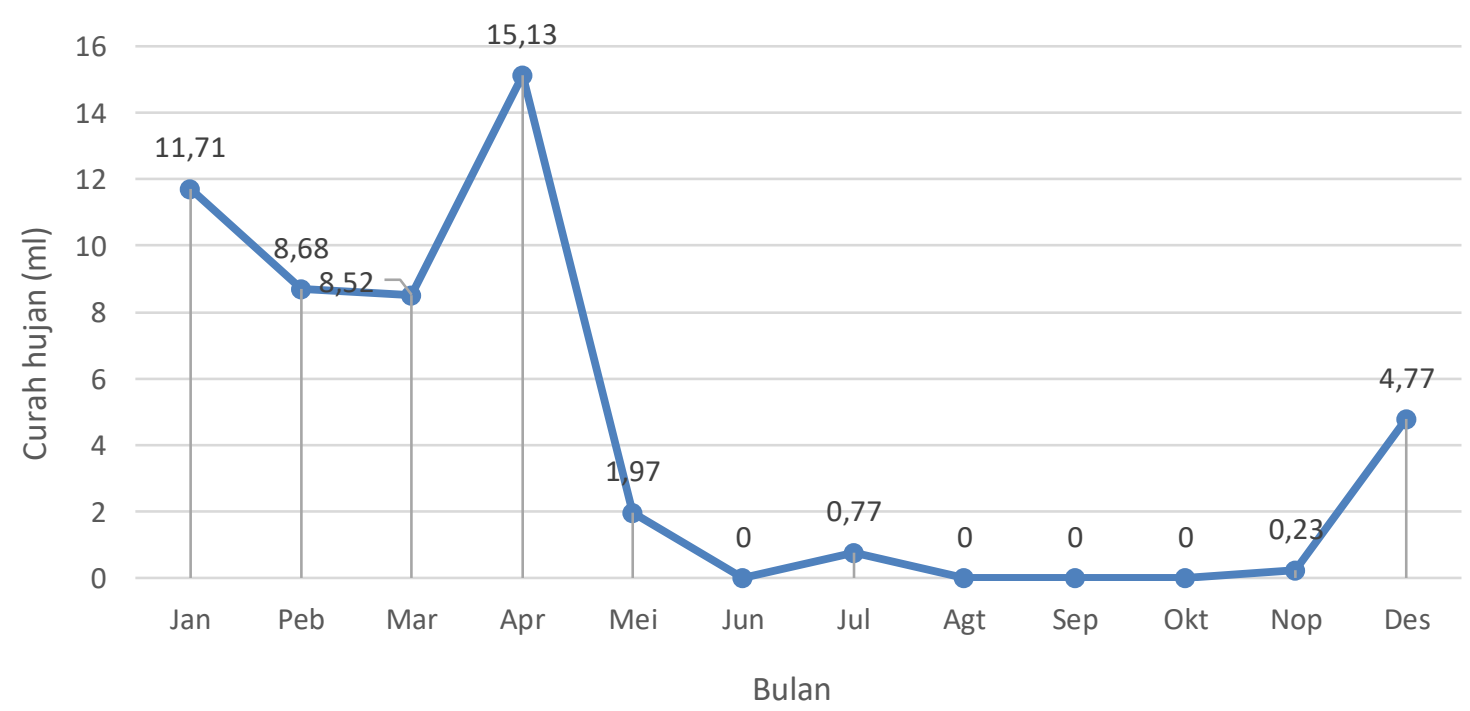

Gambar 1. Nilai curah hujan bulanan selama tahun 2019 di wilayah Kec. Purwodadi, Kabupaten Pasuruan. 
Terdapat total 16 jenis gulma yang dijumpai di lahan percobaan Desa Purwodadi, yaitu Paspalum conjugatum, Ipomoea aquatic, Blainvillea acmella, Bidens Pilosa, Synedrella nodiflora, Aeschynomene elegans, Persicaria barbata, Euphorbia hirta, Cyanthillium cinereum, Cynodon dactylon, Merremia emarginata, Desmodium gangeticum, Mimosa pudica, Eclipta prostrata, Commelina benghalensis, dan Sphaeranthus africanus. Dari 16 jenis yang diinventarisir, 7 jenis merupakan invasif spesies, sementara 9 lainnya adalah non invasif spesies. Invasif spesies merupakan jenis-jenis tanaman yang memiliki karakter antara lain adalah mampu mendominasi semua bagian ekosistem alami atau asli dan menyebabkan spesies asli menjadi punah (Tjitrosoedirdjo et al., 2016). Salah satu gulma invasif adalah $P$. conjugatum yang merupkan gulma dengan nilai INP yang terbesar dan mendominasi area lahan percobaan. Dua spesies dengan ranking di bawahnya yaitu I. aquatica masuk dalam invasif spesies dan $B$. acmella masuk dalam list non invasif spesies menurut CABI. Beberapa jenis gulma yang termasuk jenis gulma invasif dan non invasif ditunjukkan pada Gambar 2.

Tabel 2. Jenis, kelimpahan, dan dominansi tumbuhan bawah di lahan percobaan uwi di Kecamatan Purwodadi, Kabupaten Pasuruan

\begin{tabular}{lccccc}
\hline Spesies & KR & FR & DR & INP & Invasif \\
\hline P. conjugatum & 36,04 & 18,82 & 16,46 & 71,32 & $\mathrm{~V}$ \\
I. aquatica & 12,99 & 15,29 & 12,35 & 40,63 & $\mathrm{v}$ \\
S. acmella & 8,12 & 11,76 & 8,23 & 28,11 & - \\
B. pilosa & 7,47 & 9,41 & 7,20 & 24,08 & $\mathrm{v}$ \\
S. nodiflora & 5,19 & 7,06 & 5,76 & 18,01 & $\mathrm{v}$ \\
A. elegans & 3,57 & 8,24 & 5,14 & 16,95 & - \\
P. barbata & 4,87 & 3,53 & 5,56 & 13,96 & - \\
E. hirta & 2,92 & 5,88 & 4,53 & 13,33 & $\mathrm{v}$ \\
C. cinereum & 3,25 & 4,71 & 4,94 & 12,89 & - \\
C. dactylon & 4,87 & 2,35 & 5,56 & 12,78 & $\mathrm{~V}$ \\
M. emarginata & 3,57 & 3,53 & 5,14 & 12,24 & - \\
D. gangeticum & 3,57 & 2,35 & 5,14 & 11,07 & - \\
M. pudica & 1,95 & 3,53 & 3,50 & 8,98 & - \\
E. prostrata & 0,65 & 1,18 & 3,70 & 5,53 & - \\
C. benghalensis & 0,65 & 1,18 & 3,70 & 5,53 & $\mathrm{v}$ \\
S. africanus & 0,32 & 1,18 & 3,09 & 4,59 & - \\
\hline
\end{tabular}

Catatan: KR= Kelimpahan Relatif, FR= Frekuensi Relatif, DR= Dominansi Relatif, INP= Indeks Nilai Penting, $\mathrm{v}=$ tanaman invasif, - = tanaman non invasif

Hasil analisis biplot yang dilakukan terhadap faktor lingkungan dan parameter pertumbuhan tanaman uwi. Tanaman uwi menunjukkan setidaknya terdapat tiga grup aksesi yang menunjukkan respon pertumbuhan atas faktor lingkungan yang berbeda, yaitu grup I meliputi aksesi 42, 43, dan 57, grup II meliputi aksesi 28, 36 dan 66, serta grup III yaitu aksesi nomor 86 (Gambar 3). 

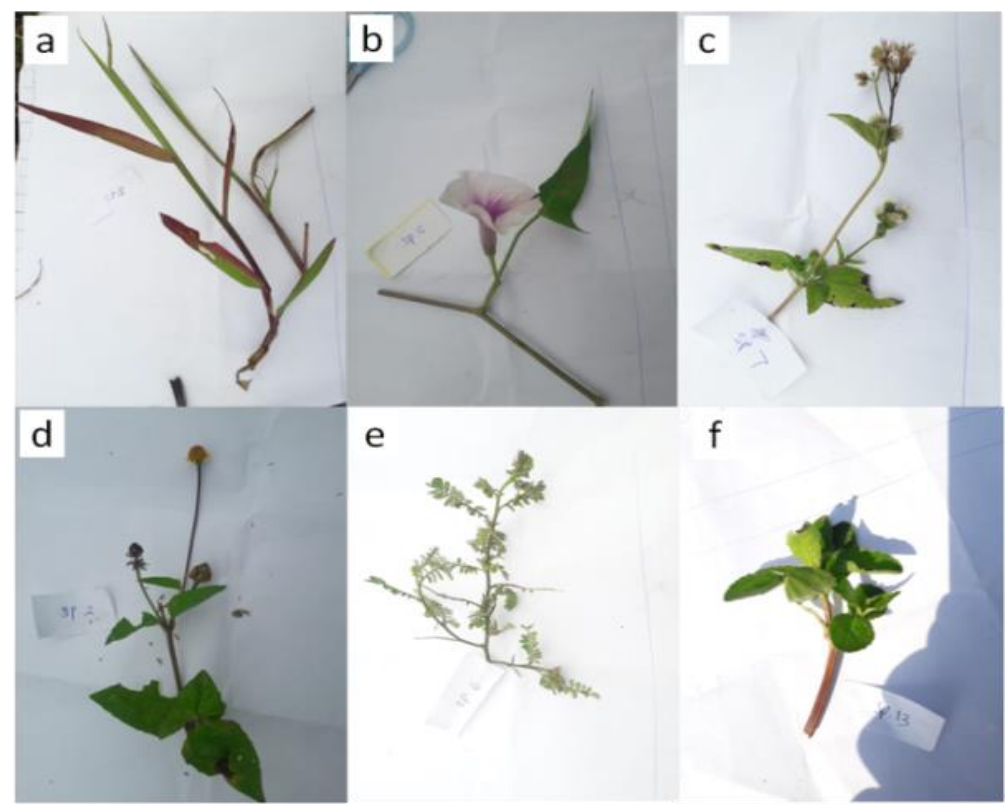

Gambar 2. Beberapa jenis gulma di lahan percobaan. Gulma invasif: a). P. conjugatum, b). I. aquatica, c). B. pilosa. Gulma non invasif: d). B. acmella, e). A. elegans, f). P. barbata

Hasil analisis biplot juga menunjukkan bahwa uwi dengan aksesi 42, 43 dan 57 adalah aksesi yang paling adaptif tumbuh di area lahan percobaan ini karena pertumbuhannya yang paling baik (lingkar batang dan jumlah tanaman berbunga).

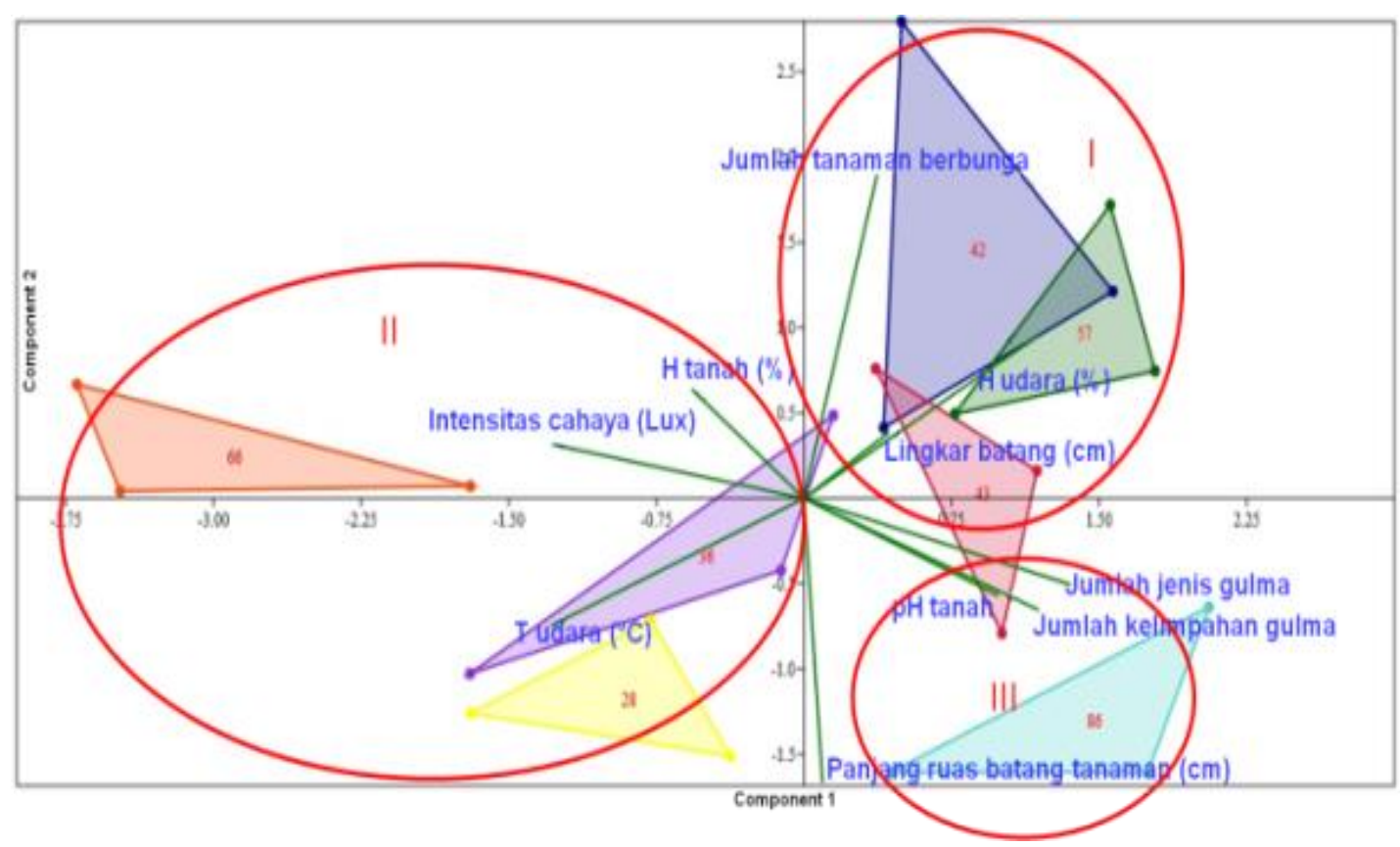

Gambar 3. Hasil analisis Biplot pengaruh faktor lingkungan terhadap pertumbuhan tanaman uwi di lahan percobaan Purwodadi, Pasuruan. Ket: H: Kelembaban, T: Suhu; Nilai dari Komponen 1 (PC 1) menjelaskan 40,00\% dari semua faktor yang diamati, sedangkan komponen 2 (PC 2) menjelaskan 27,82\%. 
Nilai eigen value untuk masing-masing parameter yang diukur yaitu faktor lingkungan dan parameter pertumbuhan ditampilkan pada Tabel 3. Secara umum, hasil penelitian menunjukkan bahwa intensitas cahaya dan jumlah gulma merupakan faktor lingkungan yang paling mempengaruhi pertumbuhan tanaman uwi karena masing-masing memiliki nilai yang tinggi dalam komponen 1 (PC 1) dan komponen 2 (PC 2) seperti ditunjukkan pada Tabel 3.

Tabel 3. Eigen value dari faktor lingkungan terhadap pertumbuhan uwi

\begin{tabular}{lrr}
\hline & PC 1 & PC 2 \\
\hline Eigenvalue & $\mathbf{4 , 0 0}$ & $\mathbf{2 , 7 8}$ \\
Faktor lingkungan & & \\
IC (Intensitas cahaya) & $-0,47$ & 0,07 \\
Suhu udara & 0,27 & $-0,41$ \\
Kelembaban udara & 0,40 & $-0,06$ \\
pH tanah & $-0,35$ & 0,15 \\
Kelembaban tanah & $-0,22$ & $-0,08$ \\
$\quad$ Jumlah gulma & 0,43 & 0,29 \\
$\quad$ Kelimpahan gulma & 0,33 & 0,39 \\
Parameter pertumbuhan & & \\
$\quad$ Panjang ruas batang & $-0,10$ & 0,57 \\
$\quad$ Lingkar batang & 0,14 & 0,05 \\
$\quad$ Jumlah tanaman & 0,22 & $-0,47$ \\
$\quad$ berbunga & & \\
\hline
\end{tabular}

Tanaman uwi berdasarkan uraian dari Kementrian Pertanian, merupakan tanaman pangan yang sebagian besar ditanam di lahan kering seperti tegalan, ladang dan kebun. Lahan percobaan uwi di Kecamatan Purwodadi, terletak di dataran rendah. Dataran rendah menurut (Raharjeng, 2015), memiliki tingkat kelembaban rendah (30$40 \%)$, dan suhu udara yang tinggi $\left(>25^{\circ} \mathrm{C}\right)$. (Abdillah, 2015) menyatakan, uwi merupakan tanaman yang tahan terhadap keadaan minim air dan adaptif tumbuh di daerah dataran rendah kering. Kondisi lahan percobaan yang termasuk dataran rendah kering dengan suhu berkisar $29,23^{\circ} \mathrm{C}$ $40,60^{\circ} \mathrm{C}$ dan kelembaban udara rendah $57,83 \%$, cukup potensial bagi pertumbuhan uwi. Hasil penelitian lain pada beberapa wilayah di Nigeria menunjukkan bahwa kisaran suhu yang disarankan untuk pertumbuhan Dioscorea alata adalah antara $21,00^{\circ} \mathrm{C}-30,50^{\circ} \mathrm{C}$ yang dapat menghasilkan pertumbuhan dan hasil panen yang baik (Eruola et al., 2011). Selain suhu udara yang cukup tinggi, intensitas cahaya di lokasi ini juga tergolong tinggi yaitu mencapai 12456 lux sehingga semakin mendukung pertumbuhan uwi. Intensitas cahaya ini sangat dibutuhkan oleh tumbuhan untuk bertahan hidup, cahayanya yang mencapai dasar tanah memicu pertumbuhan tanaman (Andika et al., 2017).

Selain iklim, karakter tanah juga memberikan pengaruh yang cukup signifikan pada pertumbuhan tanaman. Salah satunya adalah $\mathrm{pH}$ tanah. Tanaman yang toleran, mampu beradaptasi pada $\mathrm{pH}$ tanah yang bervariasi, namun yang intoleran tidak akan tahan pada naikturunnya $\mathrm{pH}$ tanah (Karamina et al., 2018). Kondisi lahan percobaan tanaman uwi memiliki pH cenderung asam dengan kisaran 4,20-5,93, kondisi tanah dengan rentang $\mathrm{pH}$ tersebut termasuk dalam kategori kurang sesuai untuk lahan pertanian (Yuwono, 2009), hal ini tentu saja sangat mempengaruhi pertumbuhan vegetatif tanaman uwi. Selain rendahnya nilai $\mathrm{pH}$ tanah, kondisi tanah di lahan percobaan juga memiliki ketersediaan air yang sangat rendah, sehingga dapat dikatakan tanah di lahan percobaan ini termasuk lahan sub optimal, dilihat dari rendahnya $\mathrm{pH}$ tanah dan minimnya air (Kanzler et al., 2015; Yuwono, 2009). Meskipun dikatakan bahwa $D$. alata dapat hidup di kondisi tanah yang cenderung beragam $\mathrm{pH}$ nya, mulai dari tanah netral 
cenderung asam hingga tanah basa (Shiwachi et al., 2015), namun pada penelitian yang lain diketahui bahwa kondisi tanah yang asam tidak memberikan hasil yang lebih baik daripada kondisi tanah yang cenderung netral (Diby et al., 2009; Diby et al., 2011). Kondisi pH tanah yang cenderung asam, bisa sangat mempengaruhi pertumbuhan tanaman budidaya, sebaliknya kondisi $\mathrm{pH}$ tanah yang mendekati netral akan lebih baik bagi pertumbuhan tanaman, hal ini terkait dengan peredaran mineralmineral dalam tanah, seperti $\mathrm{Al}, \mathrm{Mn}$, dan $\mathrm{Cu}$ yang bersifat toxic bagi tanaman, dan $\mathrm{P}$ serta $\mathrm{N}$ yang bermanfaat bagi tanaman (Emerson et al., 2009; Hernández \& Munné-Bosch, 2015; Razaq et al., 2017; Sheoran et al., 2010).

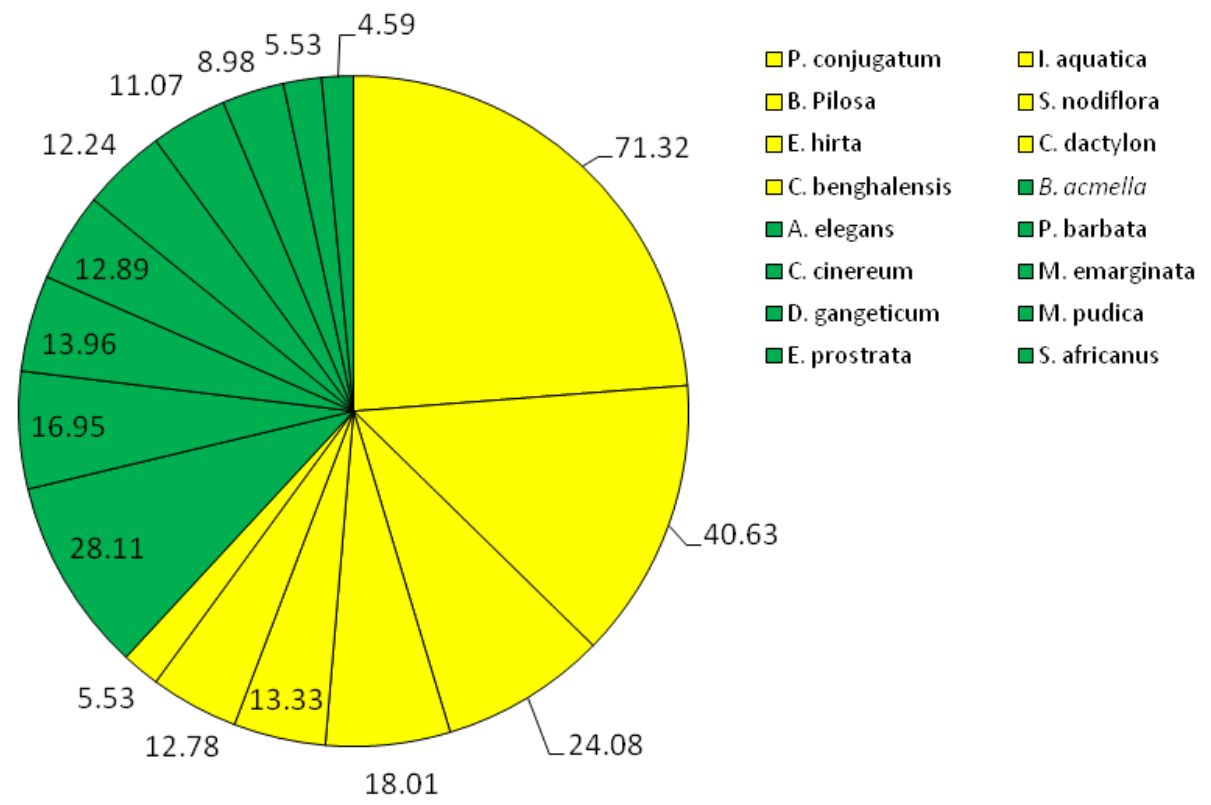

Gambar 4. Perbandingan nilai INP gulma di area lahan percobaan. Ket: Warna hijau adalah gulma non invasif dengan total jumlah nilai INP sebesar $114,31 \%$, warna kuning adalah gulma invasif dengan jumlah total nilai INP adalah $185,69 \%$.

Hasil inventarisasi gulma di area lahan percobaan, $P$. conjugatum merupakan tanaman dengan INP tertinggi. $P$. conjugatum merupakan gulma berjenis rumput-rumputan yang dijumpai pada lahan tanaman perkebunan dan lahan tanaman pangan (Adriadi et al., 2012). Menurut Plant Database, spesies ini dapat hidup di berbagai jenis tanah, mulai tanah liat, lumpur dan berpasir sekalipun, dengan $\mathrm{pH}$ mulai dari 5-7 dan tumbuh subur pada tempat yang memiliki kesuburan yang rendah sehingga disebut hipertoleran (dapat tumbuh di daerah yang memiliki unsur hara yang minim. Lestari et al. (2019) juga menyatakan $P$. conjugatum sangat toleran terhadap kondisi tanah yang sangat asam. Keberadaan P.conjugatum yang mendominasi area, menunjukkan bahwa tanah di lahan percobaan cenderung asam. Adriadi et al. (2012), mengatakan bahwa $P$. conjugatum berkembang biak dengan biji dan stolon, sehingga memiliki peluang tumbuh yang besar, dapat tumbuh dimana-mana, dan satu individunya dapat menghasilkan 1500 biji dan biji tersebut mudah menyebar sehingga memiliki peluang untuk tumbuh dan berkembang biak yang semakin besar. 
Karena nilai INP dari $P$. conjugatum cukup jauh bila dibandingan $I$. aquatica yang memiliki nilai INP di bawahnya, maka dapat dikatakan bahwa $P$. conjugatum mendominasi vegetasi tumbuhan bawah di area lahan percobaan. Secara keseluruhan, nilai INP gulma invasif lebih tinggi daripada nilai INP gulma non invasif (Gambar 4). Hal ini perlu menjadi pertimbangan dalam pengelolaan lahan, karena tanaman invasif dapat mengganggu produktivitas tanaman komoditas utama dengan cara mendominasi area dan memonopoli unsur hara dalam tanah (Lestari et al., 2019). Keberadaan gulma diketahui dapat menurunkan intensitas cahaya dan ketersediaan hara untuk tanaman, sehingga mengakibatkan penurunan pertumbuhan, produktivitas hasil, kualitas tanaman serta menyulitkan panen tanaman (Santosa et al., 2006).

Penyiangan gulma, terutama yang invasif sangat perlu untuk dilakukan, sehingga tidak akan mempengaruhi hasil produksi dan pertumbuhan uwi secara langsung. Pertumbuhan uwi berdasarkan penelitian yang dilakukan (Kiba et al., 2020), dipengaruhi oleh beberapa faktor, dan salah satunya adalah managemen gulma. (Nursanti \& Adriadi, 2018) menyatakan bahwa tumbahan invasif yang telah menyebar luas, dapat memberikan dampak negatif baik ekologis maupun ekonomis pada lingkungan di sekitarnya, terutama dalam hal perebutan unsur hara dan zat mineral dalam tanah dengan tanaman komoditas utama. Lebih jauh lagi sifat invasif pada jenis-jenis tertentu akan menimbulkan kerusakan pada spesies asli, ekosistem, pertanian, bahkan keselamatan manusia, sehingga penilaian resiko perlu untuk dilakukan (Widiyanto, 2012). Salah satu hal yang dapat diupayakan adalah mencari agen hayati yang efektif dan secara substansial dapat mereduksi pertumbuhannya, sehingga dampak tumbuhan invasif ini akan turun (Tjitrosoedirdjo et al., 2016). Namun hal yang paling sederhana seperti penyiangan secara manual, akan sangat membantu memecahkan masalah di lahan pertanian. Hasil penelitian (Santosa et al., 2006) menyebutkan bahwa frekuensi penyiangan gulma berpengaruh terhadap pertumbuhan dan hasil umbi. Jumlah daun pada Amorphophallus paeoniifolius lebih banyak dan memiliki umur daun yang lebih lama dengan frekuensi penyiangan gulma yang lebih sering.

Faktor lingkungan baik biotik maupun abiotik berpengaruh pada pertumbuhan tanaman uwi. Berdasarkan nilai eigen value yang ditampilkan pada Tabel 3 menunjukkan bahwa, intensitas cahaya dan jumlah spesies gulma memberikan pengaruh pada pertumbuhan tanaman uwi. Intensitas cahaya menjadi faktor yang berpengaruh penting pada budidaya uwi, karena intensitas cahaya akan secara langsung mempengaruhi iklim mikro, yaitu temperatur dan kelembaban udara. Kondisi kering dengan intensitas cahaya yang tinggi, menjadi kondisi yang optimal bagi pertumbuhan Dioscorea (Abdillah, 2015; Andika et al., 2017; Mukti et al., 2016).

Pertumbuhan uwi juga dipengaruhi oleh jumlah spesies gulma, bukan hanya kelimpahannya. Jika jumlah spesies tinggi, maka diperkirakan tidak akan ada dominansi dari satu spesies saja, sehingga pertumbuhan invasif spesies akan terhambat oleh adanya spesies lain yang bisa jadi merupakan agen hayatinya. Selain itu, keberagaman yang tinggi dalam suatu ekosistem akan memberi nilai lebih dalam kawasan tersebut dan memberikan jasa layanan lingkungan yang lebih baik pada 
ekosistem tersebut (Bereczki et al., 2014; Isbell et al., 2011; Wu, 2013).

Aksesi nomor 42, 43 dan 57 dikelompokkan dalam grup I. Grup ini pertumbuhannya dipengaruhi oleh kelembaban udara. Aksesi nomor 28, 36 dan 66, berada dalam grup II, di mana pertumbuhannya dipengaruhi oleh kelembaban tanah, intensitas cahaya dan suhu udara. Sedangkan grup III terdapat aksesi nomor 86 dimana pertumbuhannya dipengaruhi oleh $\mathrm{pH}$ tanah dan juga jumlah jenis dan kelimpahan gulma. Pengelompokan ketiga grup ini terjadi karena pertumbuhannya dipengaruhi oleh faktor yang berbeda-beda, sehingga pada program budidaya selanjutnya perlu diperhatikan faktor yang paling mempengaruhi pertumbuhan masingmasing grup di area lahan budidaya.

Faktor lingkungan yang berbeda memberi pengaruh yang berbeda pula pada masingmasing aksesi. Faktor-faktor yang mempengaruhi pertumbuhan tanaman uwi jelas akan mempengaruhi produktivitas umbinya. Sehingga penting sekali untuk memperhatikan bahan organik tanah yang dapat mempengaruhi produktifitas tanaman (Diby et al., 2009), faktor lingkungan, serta penyiangan gulma yang dapat mempengaruhi pertumbuhan dan produktifitas tanaman berumbi (Santosa et al., 2006). Berdasarkan kondisi lingkungan di lahan percobaan yang termasuk dalam kategori lahan sub optimal, direkomendasikan beberapa aksesi yang dapat dibudidayakan dan dikembangkan pada lingkungan tersebut yaitu aksesi 42, 43 dan 57. Sehingga pembudidayaan aksesi tertentu untuk memanfaatkan keunggulan nutrisi yang dimilikinya, memerlukan pertimbangan faktor lingkungan yang sesuai di lahan budidaya untuk mendapatkan hasil yang optimal.

\section{SIMPULAN}

1. Faktor lingkungan baik biotik maupun abiotik, memberi pengaruh bagi pertumbuhan tanaman uwi. Intensitas cahaya dan jumlah jenis gulma merupakan faktor lingkungan yang paling berpengaruh pada pertumbuhan tanaman uwi.

2. Aksesi nomor 28, 36 dan 66, pertumbuhannya dipengaruhi oleh intensitas cahaya, kelembaban tanah dan suhu udara. Aksesi 42, 43 dan 57 dipengaruhi oleh kelembaban udara. Sementara aksesi nomor 86 dipengaruhi oleh $\mathrm{pH}$ tanah, jumlah jenis gulma dan kelimpahan gulma.

3. Aksesi nomor 42, 43, dan 57, direkomendasikan untuk dibudidayakan di lahan sub optimal dengan kondisi $\mathrm{pH}$ asam dan minim air.

\section{DAFTAR PUSTAKA}

Abdillah, R. (2015). Perbaikan Ruang Tumbuh Umbi Uwi (Dioscorea alata L.) dan Pengaruhnya terhadap Pertumbuhan dan Produktivitas Umbi. Institut Pertanian Bogor.

Adriadi, A., Chairul, \& Solfiyeni. (2012). Analisis vegetasi gulma pada Perkebunan Kelapa Sawit (Elais quineensis jacq.) di Kilangan, Muaro Bulian, Batang Hari. Jurnal Biologi Universitas Andalas, 1(2), 108-115.

Andika, E. D., Kartijono, N. E., \& Rahayu, E. S. (2017). Struktur dan komposisi Tumbuhan pada lantai hutan jati di kawasan RPH Bogorejo BKPH Tanggel Blora. Life Science, 6(1), 24-33. 
Anokye, M., Tetteh, J. P., \& Otoo, E. (2014). Morphological characterization of some water yam (Dioscorea alata L.) germplasm in Ghana. Journal of Agricultural Science and Technology, 4, 518-532.

Baah, F. D. (2009). Characterization of water yam (Dioscorea alata) for existing and potential food products. Kwame Nkrumah University of Science and Technology.

Bereczki, K., Ódor, P., Csóka, G., Mag, Z., \& Báldi, A. (2014). Effects of forest heterogeneity on the efficiency of caterpillar control service provided by birds in temperate oak forests. Forest Ecology and Management, 327, 96105.

https://doi.org/10.1016/j.foreco.2014. 05.001

Bhandari, M. R., Kasai, T., \& Kawabata, J. (2003). Nutritional evaluation of wild yam (Dioscorea spp.) tubers of Nepal. Food Chemistry, 82(4), 619-623. https://doi.org/10.1016/\$03088146(03)00019-0

Diby, L. N., Hgaza, V. K., Tie, T. B., Assa, A., Carsky, R., Girardin, O., \& Frossard, E. (2009). Productivity of yams (Dioscorea spp.) as affected by soil fertility. Journal of Animal \& Plant Sciences, 5(2), 494506. Retrieved from http://www.biosciences.elewa.org/JA PS;

Diby, L. N., Tie, B. T., Girardin, O., Sangakkara, R., \& Frossard, E. (2011). Growth and nutrient use efficiencies of yams ( Dioscorea spp.) grown in two contrasting soils of West Africa. International Journal of Agronomy, 2011, 1-8. https://doi.org/10.1155/2011/175958

Emerson, P., Skousen, J., \& Ziemkiewicz, P. (2009). Survival and growth of hardwoods in brown versus gray sandstone on a surface mine in West Virginia. Journal of Environmental Quality, 38(5), 1821-1829. https://doi.org/10.2134/jeq2008.0479

Eruola, A. O., Bello, N. J., Ufoegbune, G. C., \& Makinde, A. A. (2011). Effect of variety selection on growth, development and yield of white yam in Southwestern Nigeria. Libyan Agriculture Research Center Journal Internation, 2(6), 244248.

Fauziah, Budiharta, S., Mas'udah, S., Hapsari, L., Darmayanti, A. S., Masrum, A., \& Albukorin. (2017). Laporan Kegiatan Produk Komersial Tahun 2017: Pengolahan uwi unggul (Dioscorea alata L.) menjadi produk tepung fungsional. Pasuruan.

Fauziah, \& Mas'udah, S. (2015). Explorations diversity of Dioscorea spp. varieties from Pasuruan, East Java: Inventory and characterization. Agrivita, 37(3), 193-203.

https://doi.org/10.17503/Agrivita-

2015-37-3-p193-203

Fauziah, Mas'udah, S., Hapsari, L., \& Nurfadilah, S. (2020). Biochemical composition and nutritional value of fresh tuber of water yam (Dioscorea alata L.) local accessions from East Java, Indonesia. AGRIVITA Journal of Agricultural Science, 42(2), 255-271. https://doi.org/https://doi.org/10.175 03/agrivita.v0i0.2552

Fauziah, Solikin, Mas'udah, S., Hapsari, L., Nurfadilah, S., Kasmari, \& Hadiyatmoko, T. (2017). Seleksi dan pengembangan aksesi Dioscorea sebagai sumber pangan alternatif. Pasuruan.

Hapsari, R. T. (2014). Prospek uwi sebagai pangan fungsional dan bahan diversifikasi pangan. Buletin Palawija, 
O(27),

26-38.

https://doi.org/10.21082/bulpalawija. v0n27.2014.p26-38

Harzau, H., \& Estiasih, T. (2013). Karakteristik cookies umbi interior uwi putih (Kajian proporsi tepung uwi: pati jagung dan penambahan margarin ). Pangan Dan Agroindustri, 1(1), 138-147.

Hasan, F. (2010). Peran luas panen dan produktivitas terhadap pertumbuhan produksi tanaman pangan di Jawa Timur. Jurnal Agribisnis Fakultas Pertanian Universitas Trunojoyo, 7(1), 3-8.

Herison, C., \& Turmudi, E. (2010). Studi kekerabatan genetik aksesi uwi (Dioscorea sp ) yang dikoleksi dari beberapa daerah di Pulau Jawa dan Sumatera. Akta Agrosia, 13(1), 55-61.

Hernández, I., \& Munné-Bosch, S. (2015). Linking phosphorus availability with photo-oxidative stress in plants. Journal of Experimental Botany, 66(10), 2889-2900.

https://doi.org/10.1093/jxb/erv056

Isbell, F., Calcagno, V., Hector, A., Connolly, J., Harpole, W. S., Reich, P. B., ... Loreau, M. (2011). High plant diversity is needed to maintain ecosystem services. Nature, 477(7363), 199-202. https://doi.org/10.1038/nature10282

Kanzler, M., Böhm, C., \& Freese, D. (2015). Impact of $P$ fertilisation on the growth performance of black locust (Robinia pseudoacacia L.) in a lignite postmining area in Germany. Annals of Forest Research, 58(1), 39-54. https://doi.org/10.15287/afr.2015.303

Karamina, H., Fikrinda, W., \& Murti, A. T. (2018). Kompleksitas pengaruh temperatur dan kelembaban tanah terhadap nilai $\mathrm{pH}$ tanah di perkebunan jambu biji varietas kristal (Psidium guajava I.) Bumiaji, Kota Batu. Kultivasi, 16(3), 430-434. https://doi.org/10.24198/kultivasi.v16 i3.13225

Kiba, D. I., Hgaza, V. K., Aighewi, B., Aké, S., Barjolle, D., Bernet, T., ... Frossard, E. (2020). A transdisciplinary approach for the development of sustainable yam (Dioscorea sp.) production in West Africa. Sustainability (Switzerland), 12(10). https://doi.org/10.3390/SU12104016

Kinasih, N. A., Saptadi, D., \& Soetopo, L. (2017). Variasi karakter morfologi tanaman uwi (Dioscorea alata L.) di Kabupaten Tuban dan Malang. Jurnal Produksi Tanaman, 5(6), 971-980.

Lestari, D. A., Fiqa, A. P., Fauziah, \& Budiharta, S. (2019). Growth evaluation of native tree species planted on post coal mining reclamation site in East Kalimantan, Indonesia. Biodiversitas, 20(1), 134143.

https://doi.org/10.13057/biodiv/d200 116

Mansur, S., Barus, H. N., \& Madauna, I. (2015). Respon pertumbuhan dan hasil ubi banggai (Dioscorea alata) jenis “ Baku Pusus" terhadap pemberian pupuk anorganik, organik dengan mulsa jerami padi. J. Agroland, 22(2), 131-137.

Martin, A. F., Azizah, F., Wulandari, D. R., \& Ermayanti, T. M. (2012). The effect of increase in $\mathrm{NaCl}$ concentration on growth and proline content of purple yam (Dioscorea alata L.) growth in vitro. Annales Bogorienses, 16(2), 1318.

Mukti, L. P. D., Sudarsono, \& Sulistyono. (2016). Keanekaragaman jenis tumbuhan obat dan pemanfaatannya di Hutan Turgo, Purwobinangun, 
Pakem, Sleman, Yogyakarta. Jurnal Biologi, 5(5), 9-19.

Munawaroh, P. S. S. J., Putri, W. D. R., \& Hapsari, L. (2018). Karakteristik fries uwi putih (Dioscorea alata) dengan kajian konsentrasi kalsium klorida dan lama blanching. Jurnal Teknologi Pertanian, 19(1), 33-42. https://doi.org/10.21776/ub.jtp.2018. 019.01.4

Nursanti, \& Adriadi, A. (2018). Keanekaragaman tumbuhan invasif di kawasan Taman Hutan Raya Sultan Thaha Saifuddin, Jambi. Media Konservasi, 23(1), 85-91.

Padhan, B., \& Panda, D. (2020). Potential of neglected and underutilized yams (Dioscorea spp.) for improving nutritional security and health benefits. Frontiers in Pharmacology, 11(April). https://doi.org/10.3389/fphar.2020.00 496

Pradini, R. N., Putri, W. D. R., \& Darmayanti, A. S. (2019). Pengaruh penambahan jenis dan konsentrasi bahan pengikat terhadap karakteristik fisik, kimia dan organoleptik hashbrown uwi putih (Dioscorea alata). Retrieved July 30, 2020, from https://d1wqtxts1xzle7.cloudfront.net /54458605/JURNAL_fix_Rizqa.pdf?150 $5697320=$ \&response-content disposition=inline\%3B+filename\%3DTh e_Effect_of_Type_and_Concentration _of.pdf\&Expires $=1607958038 \&$ Signatu re $=$ gsd2VCxo3a8gdM1fHrfDRODjZ6qiRZyB3| KkMvfP25rbubn1b $\mathrm{N}$

Purnomo, Daryono, B. S., Rugayah, Sumardi, I., \& Shiwachi, H. (2016). Genetic variability and classification of Indonesian yams (Dioscorea spp.) based on rapd analysis. Sabrao Journal of Breeding and Genetics, 48(4), 377390.
Purnomo, P., Daryono, B. S., Rugayah, R., \& Sumardi, I. (2012). Studi etnobotani Dioscorea spp. (Dioscoreaceae) dan kearifan budaya lokal masyarakat di sekitar Hutan Wonosadi Gunung Kidul Yogyakarta. Jurnal Natur Indonesia, 14(3), 191-198. https://doi.org/10.31258/jnat.14.3.19 1-198

Raharjeng, A. R. (2015). Pengaruh faktor abiotik terhadap hubungan kekerabatan tanaman Sansevieria trifasciata L. Jurnal Biota, 1(1), 33-41.

Razaq, M., Zhang, P., Shen, H. L., \& Salahuddin. (2017). Influence of nitrogen and phosphorous on the growth and root morphology of Acer mono. PLOS ONE, 12(2), 1-13. https://doi.org/10.1371/journal.pone. 0171321

Santosa, E., Sugiyama, N., Nakata, M., Mine, Y., Lee, O. N., \& Sopandie, D. (2006). Effect of weeding frequency on the growth and yield of elephant foot yams in agroforestry systems. Japanese Journal of Tropical Agriculture, 50(1), 7-14. https://doi.org/10.11248/jsta1957.50. 7

Sheoran, V., Sheoran, A., \& Poonia, P. (2010). Soil reclamation of abandoned mine land by revegetation: A review. International Journal of Soil, Sediment and Water, 3(2), 13.

Shiwachi, H., Kikuno, H., Ohata, J., Kikuchi, Y., \& Irie, K. (2015). Growth of water yam (Dioscorea alata L.) under alkaline soil conditions. Tropical Agriculture and Development, 59(2), 76-82. https://doi.org/10.11248/jsta.59.76

Takada, K., Kikuno, H., Babil, P., Irie, K., \& Shiwachi, H. (2017). Water Yam (Dioscorea alata L.) is Able to Grow in Low Fertile Soil Conditions. Tropical 
Agriculture and Development, 61(1), 814. https://doi.org/10.11248/jsta.61.8

Tjitrosoedirdjo, S., Setyawati, T., Sunardi, Subiakto, A., Irianto, R. S. B., \& Garsetiasih, R. (2016). Pedoman Analisis Risiko Tumbuhan Asing Invasif (Post Border). FORIS Indonesia.

Trimanto. (2012). Karakterisasi dan jarak kemiripan uwi (Dioscorea alata L.) berdasarkan penanda morfologi umbi. Buletin Kebun Raya, 15(1), 47-57.

Widiyanto, G. (2012). Identifikasi dan karakterisasi gulma-gulma ruderal invasif di Kebun Raya Bogor. Institut Pertanian Bogor.

Wu, J. (2013). Landscape sustainability science: Ecosystem services and human well-being in changing landscapes. Landscape Ecology, 28(6), 999-1023. https://doi.org/10.1007/s10980-0139894-9

Yuwono, N. W. (2009). Membangun kesuburan tanah di lahan marginal. Jurnal Ilmu Tanah Dan Lingkungan, 9(2), 137-141. 